\title{
Therapeutic trial in hereditary angioedema type III: Icatibant
}

\author{
Laila Sabino Garro ${ }^{*}$, Maria Helena Mattos Porter, Fernanda Komaroff, Caroline Terumi Adachi, \\ Maria Teresinha Malheiros, Yara Mello, Marisa Rosimeire Ribeiro \\ From 3rd WAO International Scientific Conference (WISC) 2014 \\ Rio de Janeiro, Brazil. 6-9 December 2014
}

\section{Background}

Hereditary angioedema (HAE) is a disease transmitted by autosomal dominant inheritance, characterized by quantitative and / or functional deficiency of $\mathrm{C} 1$ inhibitor $(\mathrm{C} 1-\mathrm{INH})$, which causes episodes of swelling, with involvement of many organs. HAE is currently divided into three groups. The HAE type III is a less frequent disorder that mainly affects women and is characterized by normal levels and activity of C1-INH.

\section{Methods}

Literature review and case description.

\section{Results}

We assessed a 33 years old female with episodes of lip angioedema and facial edema since March 2014, with no pruritus, with paresthesia, sometimes associated with suffocation, lasting up to 5 days despite of the use of corticosteroids and antihistamines. Patient remained with attacks twice a week with edema in different regions of the body. She did not use inhibitors of angiotensin converting enzyme, but she used contraceptive containing estrogen. The causes of allergic or acquired angioedema were ruled out. Laboratory investigation showed normal results for inhibitor quantitative and functional $\mathrm{C} 1$ and normal levels of $\mathrm{C} 4$ and $\mathrm{C} 1 \mathrm{q}$. The change of the oral contraceptive to another free of estrogen did not bring remission of episodes of edema. In June 2014 the patient was seen in the emergency room with dysphonia and suffocation. The patient was submitted to the standard treatment for anaphylaxis and a subcutaneous dose of Icatibant $30 \mathrm{mg}$. She had significant improvement of the symptoms in less than 1 hour. After that episode we decided to treat her with Danazol 200mg daily. Since then this patient had no more symptoms.

Edmundo Vasconcelos Hospital, Brazil

(c) 2015 Garro et al; licensee BioMed Central Ltd. This is an Open Access article distributed under the terms of the Creative Commons Attribution License (http://creativecommons.org/licenses/by/4.0), which permits unrestricted use, distribution, and reproduction in any medium, provided the original work is properly cited. The Creative Commons Public Domain Dedication waiver (http:// creativecommons.org/publicdomain/zero/1.0/) applies to the data made available in this article, unless otherwise stated. 